\title{
Profil Protein Bakteri Ureolitik
}

\author{
Idea Rahmania Machsun dan Enny Zulaika \\ Departemen Biologi, Fakultas Ilmu Alam, Institut Teknologi Sepuluh Nopember (ITS) \\ e-mail: enny@bio.its.ac.id
}

\begin{abstract}
Abstrak-Bakteri ureolitik dapat menghasilkan Urease yang dapat menghidrolisis urea. Bakteri ureolitik dapat ditemukan pada daerah berkapur yang mempunyai pH alkali. Salah satu produk metabolit pada bakteri adalah protein. Protein profiling bertujuan untuk melihat protein yang diturunkan dari organisme untuk menghasilkan informasi tentang protein organisme secara keseluruhan Tujuan dari penelitian ini adalah mengetahui profil protein dari bakteri ureolitik. Metode yang dilakukan dalam penelitian ini diantaranya isolasi dan purifikasi bakteri dari pegunungan kapur di Jawa Timur. Selanjutnya dilakukan ekstraksi protein untuk analisis protein dengan menggunakan SDS PAGE. Kesimpulan pada penelitian ini adalah pita protein yang terbentuk berjumlah 11 sampai 18 dengan rentang berat molekul antara 8-132 kDa. Isolat yang mempunyai pita protein paling banyak adalah isolat AT3 dengan jumlah pita protein 18 dengan rentang berat molekulnya 9-132 kDa. Sedangkan isolat yang mempunyai pita protein paling sedikit adalah SG3 dengan 11 dengan rentang berat molekulnya 9-124 kDa.
\end{abstract}

Kata Kunci-Bakteri Ureolitik, Kemotaksonomi, SDS PAGE, Urease.

\section{PENDAHULUAN}

B AKTERI ureolitik dapat menghasilkan Urease yang dapat menghidrolisis urea. Bakteri ureolitik memiliki keterlibatan yang besar pada presipitasi kalsium karbonat (CaCO3). Berdasarkan kemampuannya dalam melakukan preipitasi $\mathrm{CaCO} 3$, bakteri ureolitik dapat digunakan dalam aplikasi pengembangan properti pada material pasir, misalnya untuk memperkuat struktur beton [1].

Bakteri ureolitik dapat ditemukan pada stalaktit gua karst, pegunungan berkapur ataupun pada sedimen tanah. Beberapa bakteri ureolitik yang telah isolasi dari daerah berkapur ditemukan di pegunungan kapur atau gua-gua karst termasuk dalam genus bakteri Sporosarcina, Brevundimonas [2], Lysinibacillus [3], Cyanobacteria [4], Bacillus, Bulkholderia dan Pasteurella [5][6].

Bakteri ureolitik dapat ditemukan pada daerah berkapur yang mempunyai $\mathrm{pH}$ alkali. Salah satu produk metabolit pada bakteri adalah protein. Protein merupakan polipeptida yang berlipat membentuk struktur biologi yang aktif. Terdapat 2 jenis protein, yaitu protein sttruktural, contohnya protein penyusun dinding sel dan protein fungsional, contohnya enzim [7]. Profil protein merupakan penggambaran kandungan genom dari yang dimiliki oleh bakteri. Profil protein dapat digunakan sebagai klasifikasi, identifikasi dan perbandingan dalam studi bakteri [8]. Profil protein bakteri merupakan suatu penggambaran dari genom strain, oleh karena itu penentuan protein berperan penting dalam klasifikasi, identifikasi, dan perbandingan dalam studi bakteri [9].

Protein profiling bertujuan untuk melihat protein yang diturunkan dari organisme untuk menghasilkan informasi tentang protein organisme secara keseluruhan [10]. Marka potein dapat digunakan untuk mengidentifikasi berat molekul dari campuran polipeptida.

Elektroforesis sering digunakan untuk karakterisasi protein berdasarkan berat molekul. Salah satu metode elektroforesis yang sering dipakai adalah SDS PAGE (Sodium Dodecylsulphat Polyacrylamid Gel Electrophoresis) yang merupakan metode standart pengujian terhadap berat molekul protein [11]. Alasan elektroforesis digunakan dalam penelitian ini karena memiliki peran sangat penting dalam proses pemisahan molekul-molekul biologi, khususnya protein. Metode tersebut tidak mempengaruhi struktur biopolimer, serta sangat sensitif terhadap perbedaan muatan dan berat molekul yang cukup kecil [12].

Prinsip kerja SDS PAGE melibatkan denaturasi awal protein komponen dengan deterjen anionik yang juga mengikat protein, memberikan semua protein muatan negatif sebanding dengan massa molekul protein. Langkah ini diikuti dengan elektroforesis melalui akrilamida matriks gel berpori yang memisahkan protein berdasarkan massa molekul [13]. Molekul molekul yang lebih kecil akan bergerak lebih cepat pada gel, sedangkan molekul yang lebih besar akan bergerak secara lambat sehingga menghasilkan pita yang dekat dengan well pada gel [14].

\section{URAIAN PENELITIAN}

\section{A. Waktu dan Tempat Penelitian}

Penelitian ini dilaksanakan bulan April hingga Juni 2017 di Laboratorium Mikrobiologi dan Bioteknologi Departemen Biologi, Fakultas Matematika dan Ilmu Pengetahuan Alam, Institut Teknologi Sepuluh Nopember Surabaya dan Laboratorium Penelitian dan Quality Control PT. Perkebunan Nusantara XI Surabaya .

\section{B. Isolat Yang digunakan}

Isolat yang digunakan adalah isolat yang diambil dari tiga pegunungan kapur di Jawa Timur yaitu daerah Pegunungan Suci, Kecamatan Manyar, Kabupaten Gresik. Bukit Jaddih, Desa Jaddih, Kecamatan Socah, Kabupaten Bangkalan. Gua Akbar, Desa Gedongombo, Semanding, Kecamatan Tuban, Kabupaten Tuban dan telah ditumbuhkan pada medium selektif Calcium Carbonate Precipitation (CCP). Teknologi Sepuluh Nopember Surabaya.

\section{Purufikasi Isolat Bakteri Ureolitik}

Isolat bakteri yang didapatkan kemudian dilakukan purifikasi sampai diperoleh kultur murni, dengan mengambil satu isolat diambil secara aseptis dengan jarum ose, 
diinokulasikan ke permukaan media padat NA dengan metode 16 goresan dan diinkubasi pada suhu ruang \pm 24 jam. Koloni yang tumbuh diamati dan disubkultur sampai diperoleh koloni yang seragam. Berdasarkan purifikasi bakteri, didapatkan 9 isolat yang digunakan yaitu SG2, SG3, SG4, KL2, KL3, AT2, AT3, JB2, dan JB3.

\section{Preparasi Sampel Protein}

Satu ose bakteri Ureolitik diinokulasi ke dalam $100 \mathrm{ml} \mathrm{CCP}$ cair dan diinkubasi semalam pada suhu ruang. Kultur disentrifugasi $15000 \mathrm{rpm}$ selama 15 menit. Pelet disuspensi kedalam 10 ml larutan buffer Phosphate (PBS, pH 7,2). Satu $\mathrm{ml}$ suspensi dipindahkan ke dalam tabung microcentrifuge dan disentrifugasi pada $15000 \mathrm{rpm}$ selama 15 menit. Pelet ditambahkan $10 \mu \mathrm{l}$ SDS $10 \%$ dan $10 \mu \mathrm{l}$ buffer loading [0,125M Tris (hydroxymethyl) aminomethane, SDS 4\%, 2mercaptoethanol 10\%, bromophenol blue 0,2\%; pH 6,8]. Larutan sampel dan buffer loading dihomogenkan dengan menggunakan vortex dan dipanaskan selama 10 menit pada suhu $100^{\circ} \mathrm{C}$, disentrifugasi $15000 \mathrm{rpm}$ selama 1 menit. Supernatan disimpan pada $-20^{\circ} \mathrm{C}$ jika tidak langsung digunakan [9].

\section{E. Elektroforesis SDS-PAGE}

Profil protein bakteri Ureolitik ditentukan dengan metode Sodiumm Dodecyl Sulphate-Polyacrilamide Gel Electrophoresis (SDS-PAGE), melalui beberapa tahapan yaitu preparasi sampel protein, preparasi gel poliakrilamid, perakitan chamber dan glass plate, injeksi sampel protein bakteri, proses running SDS-PAGE, dan proses pewarnaan serta pencucian gel poliakrilamid. Running elektroforesis dilakukan pada tegangan $120 \mathrm{~V}$ dan arus 28 A selama 90 menit.

\section{HASIL DAN PEMBAHASAN}

Marka protein yang digunakan untuk tanda berat molekul protein menggunakan produk Vivantis ${ }^{\circledR}$ yang memiliki rentang berat molekul 10,5-175 $\mathrm{kDa}$. Profil protein pada bakteri ureolitik ditunjukkan pada Gambar 4.1. Pita protein yang terpisah mempunyai jumlah yang berbeda pada masing masing isolat. Pita protein yang terbentuk berjumlah 11 sampai 18 dengan rentang berat molekul antara 8-132 kDa. Isolat yang mempunyai pita protein paling banyak adalah isolat AT3 dengan jumlah pita protein 18 dengan rentang berat molekulnya 9-132 kDa. Sedangkan isolat yang mempunyai pita protein paling sedikit adalah SG3 dengan 11 dengan rentang berat molekulnya 9-124 kDa. Profil protein yang divisualisasikan pada Gambar 4.1 dapat mewakili keanekaragaman protein yang dimiliki oleh masing masing isolat bakteri ureolitik.

Pada hasil elektroforesis terdapat sejumlah pita protein yang memiliki ketebalan berbeda-beda. Protein yang memiliki ketebalan yang lebih besar dibandingkan protein lain menunjukkan bahwa protein tersebut memiliki konsentrasi yang tinggi. Semakin tinggi konsentrasi protein maka semakin tebal pita yang terbentuk. Hal ini sejalan dengan prinsip pergerakan molekul yang bermuatan, yakni molekul bermuatan dapat bergerak bebas di bawah pengaruh medan listrik, molekul dengan muatan dan ukuran yang sama akan terakumulasi pada zona atau pita yang sama [15].

Protein yang dialirkan dalam medium yang mengandung medan listrik menyebabkan senyawa-senyawa yang bermuatan akan bergerak dalam larutan sebagai akibat dari sifat polaritas yang berlawanan, sehingga mobilitas suatu molekul meupakan fungsi dari bentuk, ukuran molekul, dan besar tipe muatan [16].

Penggunaan SDS dan merkaptoetanol disertai dengan pemanasan akan memecah struktur tiga dimensi dari protein, terutama ikatan disulfida menjadi subunit-subunit polipeptida secara individual. SDS juga membungkus rantai protein yang tidak terikat dengan muatan negatif yang sama membentuk kompleks SDS-protein. Kompleks SDS-protein mempunyai densitas muatan yang identik dan bergerak pada gel hanya berdasarkan ukuran protein [15].

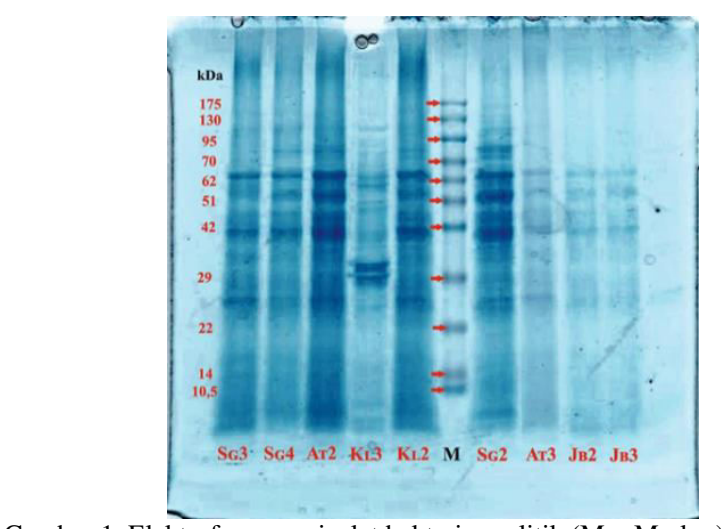

Gambar 1. Elektroforegram isolat bakteri ureolitik ( $\mathrm{M}=$ Marker).

\section{KESIMPULAN/RINGKASAN}

Kesimpulan pada penelitian ini adalah pita protein yang terbentuk berjumlah 11 sampai 18 dengan rentang berat molekul antara 8-132 kDa. Isolat yang mempunyai pita protein paling banyak adalah isolat AT3 dengan jumlah pita protein 18 dengan rentang berat molekulnya 9-132 kDa. Sedangkan isolat yang mempunyai pita protein paling sedikit adalah SG3 dengan 11 dengan rentang berat molekulnya 9-124 kDa..

\section{UCAPAN TERIMA KASIH}

Penulis mengucapkan terima kasih kepada Dr. Enny Zulaika, MP. atas dukungannya melalui pendanaan PNBP ITS tahun anggaran 2016 No. Kontrol 01711/IT2.11/PN.08.2016

\section{DAFTAR PUSTAKA}

[1] S. M. Al-Thawadi, "Ureolytic Bacteria and Calcium Carbonate Formation as a Mechanism of Strength Enhancement of Sand," J. Adv. Sci. Eng. Res., vol. 1, pp. 98-114, 2011.

[2] S. Wei, H. Cui, Z. Jiang, H. Liu, H. He, and N. Fang, "Biomineralization processes of calcite induced by bacteria isolated from marine sediments," Brazilian J. Microbiol., vol. 2, no. 46, pp. 455-464, 2015.

[3] N. K. Dhami, M. S. Reddy, and A. Mukherjee, "Biomineralization of calcium carbonates and their engineered applications: a review," Front Microbiol, vol. 4, p. 314, 2013.

[4] C. Jansson and T. Northen., "Calcifying cyanobacteria-the potential of biomineralization for carbon capture and storage," Curr Opin Biotechnol, 
vol. 21, pp. 1-7, 2010.

[5] P. Cacchio et al., "Involvement of bacteria in the origin of a newly described speleothem in the gypsum cave of Grave Grubbo (Crotone, Italy)," J. Cave Karst Stud., vol. 1, no. 74, pp. 7-18, 2012.

[6] T. Komala, "Calcite-forming bacteria located in limestone area of Malaysia," J. Asian Sci. Res., vol. 3, no. 5, pp. 471-484, 2013.

[7] B. E. Tropp, Molecular Biology Fourth Edition: Genes to Proteins. New York: Jones and Bartlett Learning, 2012.

[8] I. Kustos, B. Kocsis, I. Kerepesi, and F. Kilar., "Protein profile characterization of bacterial lysates by capillary electrophoresis," Electrophoresis, vol. 19, pp. 2317-2323, 1998.

[9] A. Aksakal, "Analysis of whole cell protein profiles of Salmonellaserovars isolated from chicken, turkey and sheep faeces by SDS-PAGE," Vet. Med. (Praha)., vol. 6, no. 55, pp. 259-263, 2010.

[10]S. A. Pizzaro, P. Lane, T. D. Lane, and E. Cruz, "Bacterial Characterozatoin using Protein Profiling in a Microchip Separations Platform,” Electrophoresis, vol. 28, no. 24, pp. 4697-4704, 2007.
[11]F.A. Rantam, Metode Imunologi. Surabaya: Airlangga University Press, 2003.

[12]Z. Bachrudin, "Petunjuk Laboratorium: Isolasi, Identifikasi, dan Pewarnaan Protein," Yogyakarta, 1999.

[13] A. B. Nowakowski, J. W. William, and H. P. David, "Native SDS-PAGE: High Resolution Electrophoretic Separation of Proteins With Retention of Native Properties Including Bound Metal Ions.," Metallomisc, vol. 6, no. 5, pp. 1068-1078, 2014.

[14]A. Grabski and R. R. Burgess, "Preparation of sampledor SDSpolyacrilamide gel electrophoresis : Procedures and tips," Novations, vol. 13, pp. 10-12, 2000

[15]S. K. S. Wijaya and R. L., "Fraksinasi dan karakterisasi protein utama biji kedelai," Jember, 2005.

[16]U. Fatmawati, Suranto, and Sajidan., "Ekspresi protein pada mikroorganisme resisten Cr dengan metode elektroforesis," Nusant. Biosience, vol. 1, pp. 31-37, 2008. 